\title{
Usefulness of Real-Time 4D Ultrasonography during Radiofrequency Ablation in a Case of Hepatocellular Carcinoma
}

\author{
Naoki Hotta $^{\mathrm{a}}$ Seigo Yamada ${ }^{\mathrm{b}}$ Kenichi Murase ${ }^{\mathrm{b}}$ \\ Kazuo Masuko ${ }^{a}$ \\ aDepartment of Internal Medicine, Division of Hepatology, Masuko Memorial \\ Hospital, and bepartment of Internal Medicine, Division of Gastroenterology, \\ Chubu Rosai Hospital, Nagoya, Japan
}

\section{Key Words}

Real-time 4D ultrasonography · Radiofrequency ablation · Hepatocellular carcinoma

\begin{abstract}
We report a case of hepatocellular carcinoma (HCC) with chronic hepatitis $C$ virus infection successfully treated with percutaneous radiofrequency ablation (RFA) under live four-dimensional (4D) echo guidance. A 65-year-old Japanese man had a HCC nodule in the liver $S 5$ region $2.0 \mathrm{~cm}$ in diameter. We performed real-time 4D ultrasonography during RFA therapy with a LeVeen needle electrode. The echo guidance facilitated an accurate approach for the needle puncture. The guidance was also useful for confirming whether an adequate safety margin for the nodule had been obtained. Thus real-time 4D ultrasonography echo technique appears to provide safe guidance of RFA needles via accurate targeting of HCC nodules, thereby allowing real-time visualization when combined with echo contrast. Furthermore the position of the needle in a still image was confirmed in every area using a multiview procedure.
\end{abstract}

\section{Introduction}

Hepatocellular carcinoma (HCC) is increasing worldwide, including the United States and Europe, and is thus a global problem $[1,2]$. Patients with chronic liver disease related to hepatitis B or C virus constitute a high-risk group for the development of HCC [3]. Surgical resection for HCC has a limited role because of underlying cirrhosis or the presence of multiple HCC lesions. Accordingly various nonsurgical therapies have been 


\begin{tabular}{r|l|l|l}
$\begin{array}{r}\text { Case Reports in } \\
\text { Gastruenterology }\end{array}$ & $\begin{array}{l}\text { Case Rep Gastroenterol 2011;5:82-87 } \\
\text { DOl: 10.1159/000321721 }\end{array}$ & $\begin{array}{l}\text { Published online: } \\
\text { February 1, 2011 }\end{array}$ & $\begin{array}{l}\text { O 2011 S. Karger AG, Basel } \\
\text { ISSN 1662-0631 } \\
\text { www.karger.com/crg }\end{array}$ \\
\hline
\end{tabular}

attempted. Among them, percutaneous therapies such as percutaneous ethanol injection, microwave coagulation and radiofrequency ablation (RFA) have been widely applied $[4,5]$. RFA may be the most promising of these treatment strategies. Studies evaluating the tumor vascularity of HCC have been conducted extensively using various imaging modalities.

The recent advances in ultrasonography (US) devices in conjunction with better contrast agents have greatly improved sensitivity in evaluating the hemodynamics of liver tumors based on the availability of real-time gray-scale harmonic US imaging [6]. Since we are expected to ablate the tumor nodule with an adequate safety margin, a more accurate procedure and positioning of the inserted needle during RFA employing more advanced devices is clearly desirable. Herein we report a case with HCC successfully treated with percutaneous RFA under real-time 4D US guidance.

\section{Case Report}

A 65-year-old Japanese man was referred to our outpatient clinic in February 2008 for treatment of a hepatic tumor. He had no remarkable past medical history other than chronic hepatitis $\mathrm{C}$ which had been followed at another outpatient clinic since 1999. Slightly elevated serum prothrombin induced by low vitamin $\mathrm{K}$ absence-II (PIVKA-II) levels had been noted and a hepatic tumor was detected on abdominal CT at a periodic examination in February 2008. He was admitted to our gastrointestinal ward in February 2008. On admission, his physical examination findings were unremarkable; neither the liver nor the spleen was palpable. There was no jaundice, ascites, peripheral edema or other sign of chronic liver disease. Laboratory test results included a white blood cell count of $4,900 / \mu 1$, hemoglobin of $14.4 \mathrm{~g} / \mathrm{dl}$, and a platelet count of $111,000 / \mu \mathrm{l}$. Liver biochemistry tests showed normal serum transaminases level (aspartate aminotransferase $46 \mathrm{IU} / \mathrm{l}$ and alanine aminotransferase $35 \mathrm{IU} / \mathrm{l}$ ) and normal total bilirubin $(0.8 \mathrm{mg} / \mathrm{dl})$. Other laboratory tests results were within normal ranges as well (table 1). The PIVKA-II level was $1,570 \mathrm{mAU} / \mathrm{ml}$ (normal $<40 \mathrm{mAU} / \mathrm{ml}$ ), and $\alpha$-fetoprotein (AFP) was within normal range $(5.0 \mathrm{ng} / \mathrm{ml})$. He was seropositive for anti-hepatitis $\mathrm{C}$ virus by a second-generation enzyme immunoassay (Dainabot, Tokyo, Japan) and the presence of serum hepatitis C virus RNA was confirmed by Amplicore (Roche Diagnostic Inc., Tokyo, Japan).

Fundamental B-mode US scan showed the presence of a low-echoic lesion in the S5 area $2.0 \mathrm{~cm}$ in diameter. On dynamic CT, the nodule showed tumor staining in the early arterial phase and washout density in the postvascular phase. We performed contrast-enhanced US with a PVT-382MV probe from APLIO XG (Toshiba Medical Systems, Otawa, Japan). The vascularity of the HCC lesion was assessed by microflow imaging using $0.5 \mathrm{ml}$ of sonazoid (Daiichi-Sankyo, Tokyo, Japan) [7]. The US imaging was focused at the base of the target tumor. The images were taken in the early vascular phase from $10 \mathrm{~s}$ until $40 \mathrm{~s}$ after injection; tumor vessel and staining were clearly observed (ig. 1 ). The CT and US findings indicated that the patient had HCC. Since he refused angiography or surgery, RFA was selected as therapy.

RFA was conducted for 12 min under a percutaneous approach using an expandable LeVeen needle with a hook $3.5 \mathrm{~cm}$ in diameter (Boston Scientific, USA). During and after the procedure, real-time 4D US was applied for accurate positioning of the needle and for confirmation of adequate ablation with a sufficient safety margin. We also confirmed the position of the needle using the multiview detector with which this model is equipped, and the solid mode which allows depiction of lesions in units of several millimeters as one area as on a CT scan. The area of the treated portion included the gallbladder, and both needle position and safety margin from the gallbladder were confirmed. It was possible to observe the tumor from multiple directions including lateral superior and inferior portions (fig. 2). Dynamic CT scan performed 3 days after RFA showed no tumor staining with a low-density area corresponding to the tumor-affected part of the liver in the early arterial phase. Dynamic CT also indicated an adequate safety margin for the nodule. After RFA treatment, contrast-enhanced US was performed and the site of the enhanced tumor was visualized as a defect (fig. 3 ). 


\begin{tabular}{r|l|l|l}
$\begin{array}{r}\text { Case Reports in } \\
\text { Gastruanterology }\end{array}$ & $\begin{array}{l}\text { Case Rep Gastroenterol 2011;5:82-87 } \\
\text { DOI: 10.1159/000321721 }\end{array}$ & $\begin{array}{l}\text { Published online: } \\
\text { February 1, 2011 }\end{array}$ & $\begin{array}{l}\text { O 2011 S. Karger AG, Basel } \\
\text { ISSN 1662-0631 } \\
\text { www.karger.com/crg }\end{array}$ \\
\hline
\end{tabular}

\section{Discussion}

This is the first report demonstrating that contrast-enhanced 4D real-time US imaging can safely and accurately guide needle puncture during RFA therapy in a patient with HCC.

US is the most commonly used imaging method for diagnosing hepatic tumors. The improvement of US devices with contrast agents appears to contribute to increased sensitivity and accuracy in evaluating the hemodynamics of hepatic tumors, e.g. the development of a new method with microflow imaging. This study demonstrated the possibility of easily assessing intratumoral blood flow dynamics in patients with hepatic tumors $[5,6]$. In addition, with the use of the contrast agent sonazoid, small vessels and low perfusion could be depicted in real time. Since the microflow imaging used herein allowed alteration of the images and serial measurements of signals in addition to the information provided by contrast agent use, suppressing the signals from surrounding tissues (liver parenchyma), it was possible to easily image the structures of fine, complex blood vessels. Also, visualization using this contrast agent can be repeated many times because it accumulates and remains in the liver for a very long time. A newly introduced $4 \mathrm{D}$ US, incorporating dynamic real-time 3D US with a continuous volume data set acquisition capacity, provided improved visualization and more valuable information on the mutual relationship between ablation and hepatic mass $[8,9]$.

The probe which we used herein was a microconvex type probe which is smaller than the one we reported previously. However the tumor depiction ability was good, though since we could not perform the desired imaging with this probe, we used other probes for puncture under real-time $4 \mathrm{D}$ biopsy with this probe. For the trace, we observed the needle and anticipate its future use for guiding accurate puncture. Despite improved US devices, we occasionally experience cases in whom accurate positioning of the RFA needle is difficult because the nodules are indistinct. There are disadvantages to using 4D US, e.g. the fact that current $4 \mathrm{D}$ ultrasonic transducers are bulkier and heavier than conventional $2 \mathrm{D}$ transducers, resulting in some difficulty in handling the probe. Moreover, the mechanical sweeping motion of the $4 \mathrm{D}$ transducer generates a mechanical vibration during the RFA procedure.

We used a real-time 4D US device for RFA therapy in the present study and confirmed that the needle was inserted accurately into the center of the target tumor. The tumor was ablated with an adequate safety margin. We easily and quickly obtained useful information regarding positioning of the needle. The device is advantageous in terms of excellent distinction between the target and surrounding tissues with rapid construction of $4 \mathrm{D}$ images and no vibration of the probe. Since this device can depict the tumor in all sections, it is possible to confirm the $3 \mathrm{D}$ positional relationships among the target, needle and adjacent organs such as large blood vessels, gallbladder and diaphragm. This will allow the RFA procedure to be performed more safely.

The technique described herein, using a real-time 4D US device, has the limitation that the probe lacks guidance for the puncture. Thus it can serve as a diagnostic but not as a therapeutic tool. It would be optimal to have the puncture guidance along with development of the corresponding contrast agents. Since we can calculate the pretreatment tumor volume, the therapeutic effect may be evaluated by calculating the posttreatment volume of the nonenhanced area. 
Table 1. Laboratory data on admission

\begin{tabular}{ll}
\hline Chemistry & \\
TP & $7.3 \mathrm{~g} / \mathrm{dl}$ \\
Alb & $3.9 \mathrm{~g} / \mathrm{dl}$ \\
T-Bil & $0.8 \mathrm{mg} / \mathrm{dl}$ \\
AST & $46 \mathrm{IU} / \mathrm{l}$ \\
ALT & $35 \mathrm{IU} / \mathrm{l}$ \\
ALP & $187 \mathrm{IU} / \mathrm{l}$ \\
$\gamma$-GTP & $32 \mathrm{IU} / \mathrm{l}$ \\
LDH & $181 \mathrm{IU} / \mathrm{l}$ \\
Na & $141 \mathrm{mEq} / \mathrm{l}$ \\
K & $3.8 \mathrm{mEq} / \mathrm{l}$ \\
Cl & $105 \mathrm{mEq} / \mathrm{l}$ \\
BUN & $12.2 \mathrm{mg} / \mathrm{dl}$ \\
Cre & $0.9 \mathrm{mg} / \mathrm{dl}$ \\
\hline CBC & \\
WBC & $4,900 / \mu l$ \\
RBC & $408,000 / \mu l$ \\
Hgb & $14.4 \mathrm{~g} / \mathrm{dl}$ \\
Hct & $43.9 \%$ \\
MCV & $107.6 \mathrm{fl}$ \\
Plt & $111,000 / \mu l$ \\
\hline Coagulation & \\
APTT & $30.6 \mathrm{~s}$ \\
PT-T & $13.7 \mathrm{~s}$ \\
PT\% & $87 \%$ \\
PT-INR & 1.10 \\
\hline Tumor marker & \\
AFP & $5.0 \mathrm{ng} / \mathrm{ml}$ \\
PIVKA-II & $1,570 \mathrm{mAU} / \mathrm{ml}$ \\
\hline Serum antibodies \\
HCV-Ab & positive \\
HBs-As & negative \\
HBs-Ab & negative \\
\hline & \\
\hline
\end{tabular}




\begin{tabular}{r|l|l|l}
$\begin{array}{r}\text { Case Reports in } \\
\text { Gastruanterology }\end{array}$ & $\begin{array}{l}\text { Case Rep Gastroenterol 2011;5:82-87 } \\
\text { DOI: 10.1159/000321721 }\end{array}$ & $\begin{array}{l}\text { Published online: } \\
\text { February 1, 2011 }\end{array}$ & $\begin{array}{l}\text { O 2011 S. Karger AG, Basel } \\
\text { ISSN 1662-0631 } \\
\text { www.karger.com/crg }\end{array}$ \\
\hline
\end{tabular}

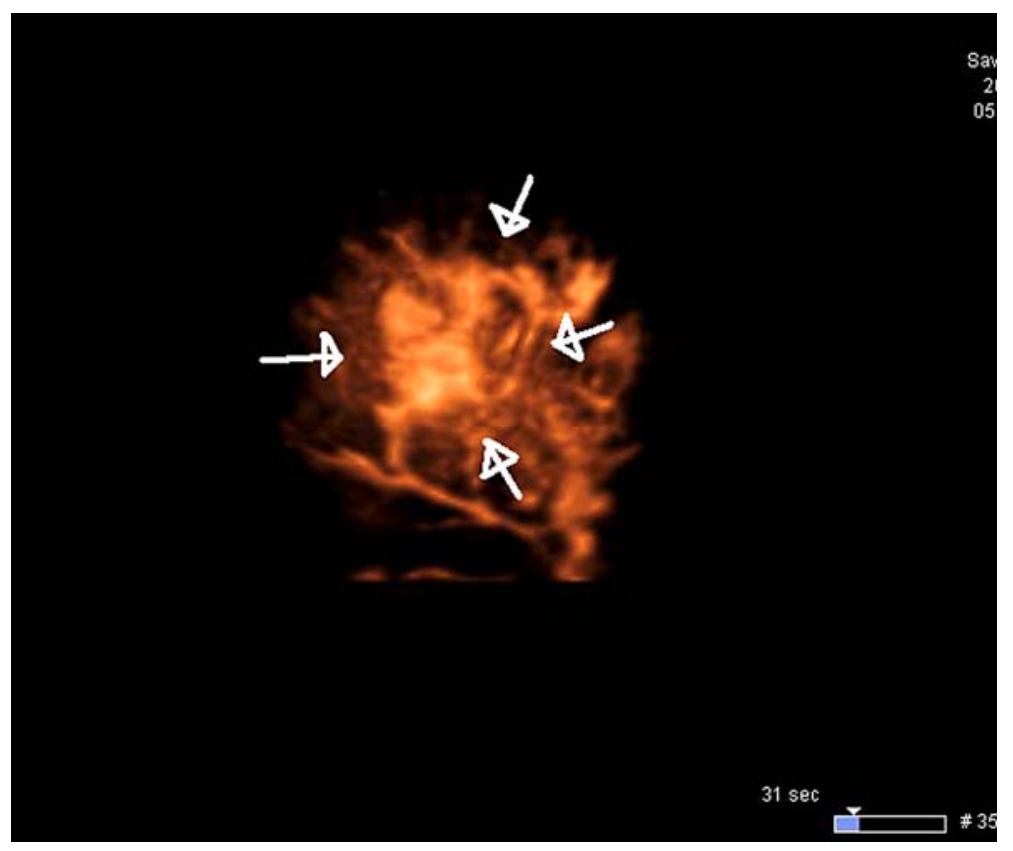

Fig. 1. On contrast-enhanced US, $3 \mathrm{~cm}$ in diameter tumor staining can be seen in the liver S5 area in the early arterial phase.

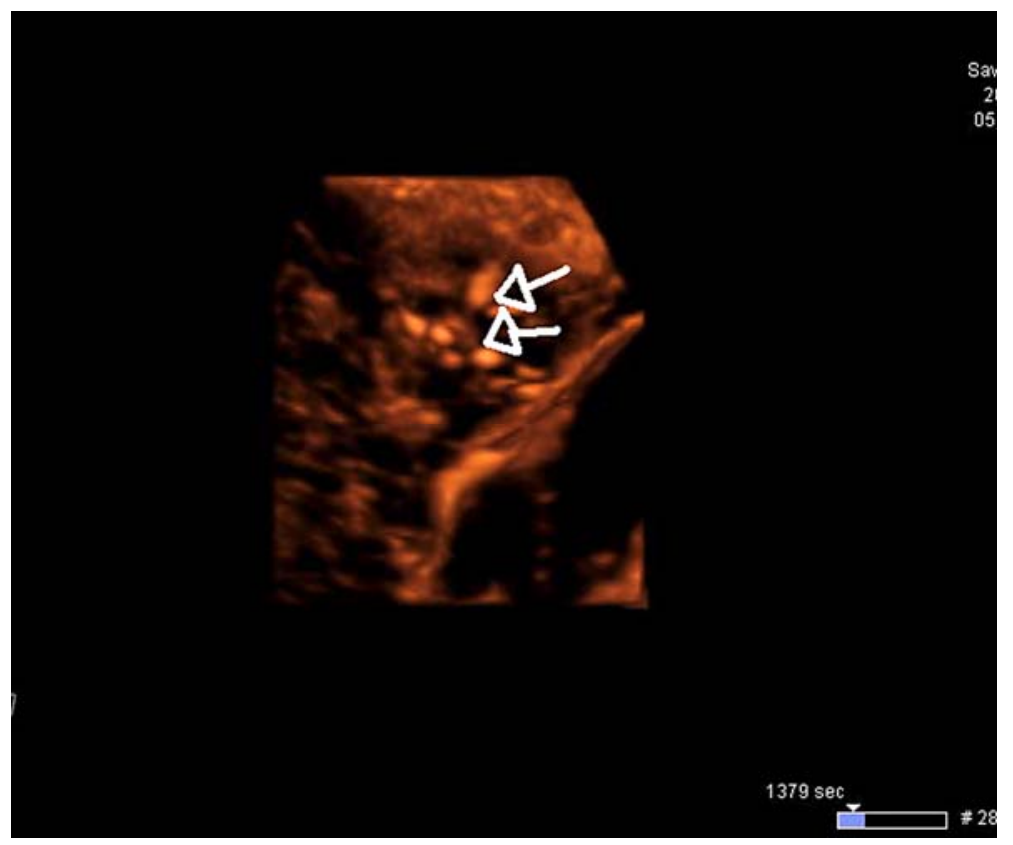

Fig. 2. On 4D mode in US, needle puncture during the RFA procedure and insertion into the center of the tumor nodule were confirmed. We also confirmed expansion of the LeVeen needle from the lower portion of the tumor. From another perspective, there was clearly a sufficient distance from the gallbadder and the needle was shown to be fully deployed. 


\begin{tabular}{c|l|l|l}
$\begin{array}{r}\text { Case Reports in } \\
\text { Gastroanterology }\end{array}$ & $\begin{array}{l}\text { Case Rep Gastroenterol 2011;5:82-87 } \\
\text { DOI: 10.1159/000321721 }\end{array}$ & $\begin{array}{l}\text { Published online: } \\
\text { February 1, 2011 }\end{array}$ & $\begin{array}{l}\text { O 2011 S. Karger AG, Basel } \\
\text { ISSN 1662-0631 } \\
\text { www.karger.com/crg }\end{array}$ \\
\hline
\end{tabular}

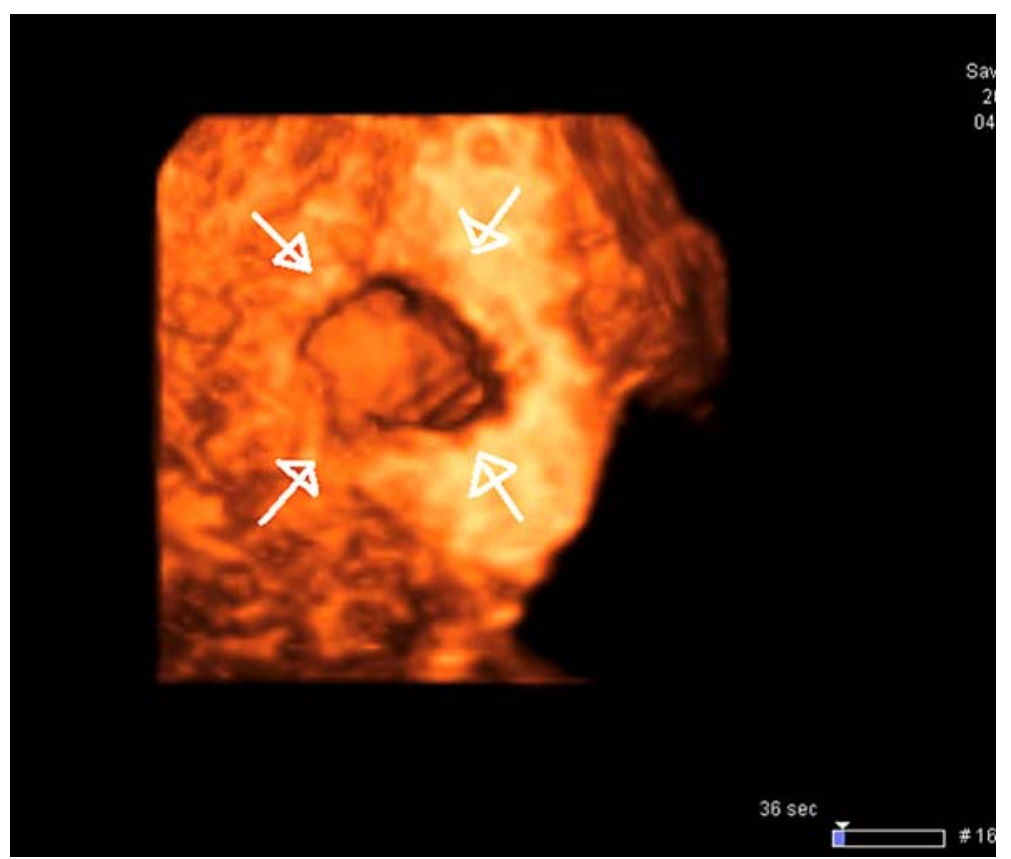

Fig. 3. After treatment, contrast-enhanced US was performed and the site of the enhanced tumor was visualized as a defect.

\section{References}

1 El-Serag HB, Mason AC: Rising incidence of hepatocellular carcinoma in the United States. N Engl J Med 1999;340:745-750.

2 Taylor-Robinson SD, Foster GR, Arora S, Hargreaves S, Thomas HC: Increase in primary liver cancer in the UK, 1979-94. Lancet 1997;350:1142-1143.

-3 Shiratori Y, Shiina S, Imamura M, et al: Characteristic difference of hepatocelluar carcinoma between hepatitis B and C viral infection in Japan. Hepatology 1995;22:1027-1033.

4 Livraghi T, Lazzaroni S, Meloni F: Radiofrequency thermal ablation of hepatocellular carcinoma. Eur J Ultrasound 2001;13:159-166.

5 Numata K, Tanaka K, Kiba T, et al: Contrast-enhanced, wide-band harmonic gray scale imaging of hepatocellular carcinoma. Correlation with helical computed tomographic findings. J Ultrasound Med 2001;20:89-98.

6 Hotta N, Maeno T, Ayada M, et al: Four-dimensional ultrasonography for therapeutic radiofrequency ablation for hepatocellular carcinoma. Hepatogastroenterology 2006;53:521-525.

7 Luo W, Numata K, Morimoto M, et al: Focal liver tumors: characterization with 3D perflubutane microbubble contrast agent-enhanced US versus 3D contrast-enhanced multidetector CT. Radiology 2009;251:287-295.

8 Ohto M, Kato H, Tsujii H, et al: Vascular flow patterns of hepatic tumors in contrast-enhanced 3-dimensional fusion ultrasonography using plane shift and opacity control modes. J Ultrasound Med 2005;24:49-57.

-9 Rose S, Hassanein T, Easter D, et al: Value of three-dimensional US for optimizing guidance for ablating focal liver tumors. J Vasc Interv Radiol 2001;12:507-515. 